\title{
A Listening Lesson Prototype for the First-Grade in Primary School
}

\author{
Katarina Retno Triwidayati ${ }^{凶}$ \& Tresiana Sari Diah Utami² \\ 1,2 Universitas Katolik Musi Charitas, Palembang, Indonesia \\ $\triangle$ retno@ukmc.ac.id
}

\begin{abstract}
One of the main purposes of learning Bahasa Indonesia is to make students be fluent in using language. Language skills consist of two receptive skills (listening and reading), and two productive skills (speaking and writing). Those four skills are expected to be practiced equally. However, based on the previous research, listening lessons were rarely implemented in class. Moreover, listening lesson were inappropriately implemented by asking students to read. Additionally, the listening tests to measure the students' listening proficiency were also unsuitable. Based on those findings, the researchers conducted a listening lesson developmental research for the first-grade primary school. This research is part of a developmental research referring to Gall, Gall, and Borg's developmental research steps. This research is the second of five planned research phases. In this second phase, the researchers developed a listening lesson prototype validated by six validators. To validate the data, this research employed the triangulation method. Meanwhile, Miles and Huberman's data analysis technique was utilized to analyze the data. The result of this research was a listening lesson prototype, including the mapping of basic competencies, networking of themes, determining of listening learning success indicators, learning stages, and listening evaluation.
\end{abstract}

Keywords: prototype, listening lesson, validation, primary school, first-grade

How to Cite: Triwidayati, K. R., \& Utami, T. S. D. (2019). A Listening Lesson Prototype for the First-Grade in Primary School. Mimbar Sekolah Dasar, 6(3), 292-303. doi:http://dx.doi.org/10.17509/mimbar-sd.v6i3.20872.

INTRODUCTION The accommodation of the four language skills in language learning has not yet been manifested, and Bahasa Indonesia in primary school is no exception.

This is evident based on the results of the previous research. The learning of Bahasa Indonesia emphasizes more on reading and writing. Additionally, the research also indicated that the students did not learn the four language skills, either partially or holistically. As a result, the learning of listening is ignored (Triwidayati, 2018).
Basically, listening requires students to receive language with their ears. In this case, students process speech to make a meaningful message (Supharatypthin, 2014). Therefore, students need to practice listening continuously. Consequently, listening lessons need to be directed towards continuous practice, so that students are able to master the skill of processing messages.

Listening skill is an active process that requires conscious effort, concentration, and interest (Bran, 2018). Hence, through listening lessons, students must develop those three aspects. 
Katarina Retno Triwidayati \& Tresiana Sari Diah Utami, A Listening Lesson Prototype for the First-Grade...

According to Field (Supharatypthin, 2014), listening involves seven sub-skills, namely (1) discrimination or a bottom-up level skill, a sub-skill enabling students to at least differentiate different words through the teacher's dictation, (2) segmentation, a sub-skill that allows students to detect words in continuous speech through the teacher's dictation, (3) exploration, a subskill that asks students to spell unfamiliar words through the teacher's dictation and the students guessing, (4) anticipation or top-down level skill, a sub-skill that requires students to complete incomplete sentences through game done by the teacher, (5) reference, a sub-skill that enables students to match pronouns with their reference items, (6) monitoring, a listening sub-skill that requires students to monitor a lengthy text for keywords (7) relevance, a listening sub-skill that requires students to identify important points by filling in tables with specific and general points.

However, in the implementation, listening lessons have not yet been satisfying. In line Utami (2016) who conducted the research towards six primary schools managed by Yayasan Xaverius Palembang, the results showed that listening was taught using the concept of teaching and learning reading. The teachers stated that there were three methods in teaching listening due to lack of learning media for listening.

The first method was text-reading by teachers. The weakness of this method is that teachers have less control over the students. As a result, teachers are not able to effectively identify students who are not paying enough attention towards the material. These students may potentially disturb other students, or fail to complete tasks.

The second method was appointing students considered fluent in reading to read texts. Although this method enables teachers to gain control of the class, however; the students reading the text lose their right to listen.

The third method was randomly asking students to read texts in turns. This method allows teachers to identify students who are paying attention to the text being read. However, the method is not considered as a listening activity.

Apart from inappropriately teaching listening, the primary schools of the research did not have valid media to teach listening. In addition, the listening materials also did not reflect local wisdom, because the stories that included in the listening materials were not from South Sumatera.

There are several reasons why the teaching and learning of listening is considered less important. One of the reasons is because listening is not included in either the Bahasa Indonesia national exam or summative tests, unlike the English subject. Hence, learning media and language laboratories are intended more for English language learning. 
In addition, another research is that lecture dominated teaching and learning is believed to be the actual form of the students' ability to listen, and consequently, there is an opinion stating that students who do not listen well will have difficulties following lessons (Widyaningrum, 2015).

The primary school teachers of the research also stated that dictation is employed for listening tests. The teachers believe that students who follow listening classes well will be able to write down the words/sentences dictated by the teacher. However, dictation is not considered as a listening test.

Based on the results of the previous research, the schools need a design for listening lessons. The design should include listening materials, comprehension questions, and media.

\section{METHOD}

This research employed the ten steps in educational research and development. The ten steps include (1) needs analysis, (2) materials analysis, (3) prototype development, (4) validity test by experts, (5) prototype revision, (6) preliminary field testing involving 1-3 classes, (7) main product revision, (8) main field testing involving 3-6 schools, (9) operational product revision, and (10) dissemination and publication of research results (Gall, Gall, \& Borg, 2003).

This research will be conducted periodically in five phases as shown in Table 1.

Table 1. Phases of the Research

\begin{tabular}{|c|c|c|c|c|}
\hline No & Phase & Activity & $\begin{array}{l}\text { Implementation } \\
\text { Target }\end{array}$ & Achievement Target \\
\hline 1 & I & Needs Analysis & $2016-2017$ & $\begin{array}{l}\text { A general and specific idea on the } \\
\text { needs of the partner schools related } \\
\text { to the teaching and learning of } \\
\text { listening }\end{array}$ \\
\hline 2 & $\|$ & $\begin{array}{l}\text { Planning, } \\
\text { prototype } \\
\text { development, } \\
\text { and validation } \\
\text { test }\end{array}$ & $2017-2019$ & $\begin{array}{l}\text { A revised prototype validated by } \\
\text { experts }\end{array}$ \\
\hline 3 & III & $\begin{array}{l}\text { Preliminary field } \\
\text { testing }\end{array}$ & $2019-2020$ & $\begin{array}{l}\text { A revised prototype after conducting } \\
\text { preliminary field testing }\end{array}$ \\
\hline 4 & IV & Main field testing & $2020-2021$ & $\begin{array}{l}\text { A revised prototype after conducting } \\
\text { main field testing }\end{array}$ \\
\hline 5 & $\mathrm{~V}$ & Dissemination & $2021-2025$ & Dissemination in the form of \\
\hline
\end{tabular}


Katarina Retno Triwidayati \& Tresiana Sari Diah Utami, A Listening Lesson Prototype for the First-Grade...

research results

published research results and

accessibility for partner school to use research results
In this second phase, the research was conducted after developing a validated prototype for listening lessons. Therefore, the research carried out observations to collect data with validation questionnaire as the instrument. Meanwhile, to validate the collected data, the triangulation method was employed by interviewing the validators after and/or at the time they were filling in the validation questionnaire. Hence, the collected data are expected to be valid.

The partner schools that participated in this research were primary schools in Palembang City managed by Yayasan Xaverius Palembang. Based on the scope of the research, the first-grade was considered to be selected. There were six validators who took part in this research. Four of the validators were experts in language learning in accordance with their educational background, experience, and researches in the field of language learning. Moreover, they were chosen because the main content of this research is the teaching and learning of Bahasa Indonesia. Meanwhile, the other two validators were certified primary school teachers. They were chosen because the results of this research will be implemented at primary school.

As shown in Table 1, in this second phase, the researcher designed, validated, and revised the prototype based on validation results.

The data analysis technique of this research was Miles and Huberman's data analysis procedure. The technique covers data presentation, data reduction, data validation, and conclusion. The researcher then correlated the data based on suggestions from the six validators. Lastly, the researcher drew a conclusion based on input from the six validators, and then made improvements to the prototype.

\section{RESULTS}

The product of this research was a listening lesson prototype for the first-grade primary school. The prototype consisted of basic competencies, themes, indicators of the success of learning listening, and listening evaluation. In the listening evaluation, the listening materials were then manifested in the form of audios and comprehension questions equipped with the scoring for each question, method in calculating grades, and reflection page to gather feedback on the listening activities.

The developed prototype was then validated and improved based on the validators' feedback.

Based on the opinions of the six validators, the developed prototype was considered valid. However, the validators suggested 
that the prototype needed to be improved. Therefore, the prototype was revised in accordance with the points suggested by the validators.

Prior to developing the prototype, the researcher reconfirmed with results of the previous research. The purpose of reconfirmation was to make sure that the research results, which are the basis of this developmental research, were still relevant in this second phase.

Reconfirmation was conducted towards the six schools of this research. The results showed that there were no changes of results from the previous research with the current condition; the schools still applied reading skills in teaching listening. As stated in the introduction, the method is considered inappropriate in teaching listening.

The reconfirmation results also showed that the schools had not yet allocated time to evaluate the students' proficiency in listening, which indicated that listening lessons were barely implemented by the schools of this research.

Assigning students considered fluent in reading or reading texts in turns was still applied by the schools. This was because the schools had not yet facilitated teachers with sufficient media to teach listening.

Besides that, the teachers still avoided downloading listening materials from the internet. According to the teachers, the students are more interested in the device used to play the listening material. As a result, the teachers decided to read texts for listening lessons.

After reconfirming results of the previous research, the researchers then developed a prototype. The prototype development process is illustrated in Figure 1.

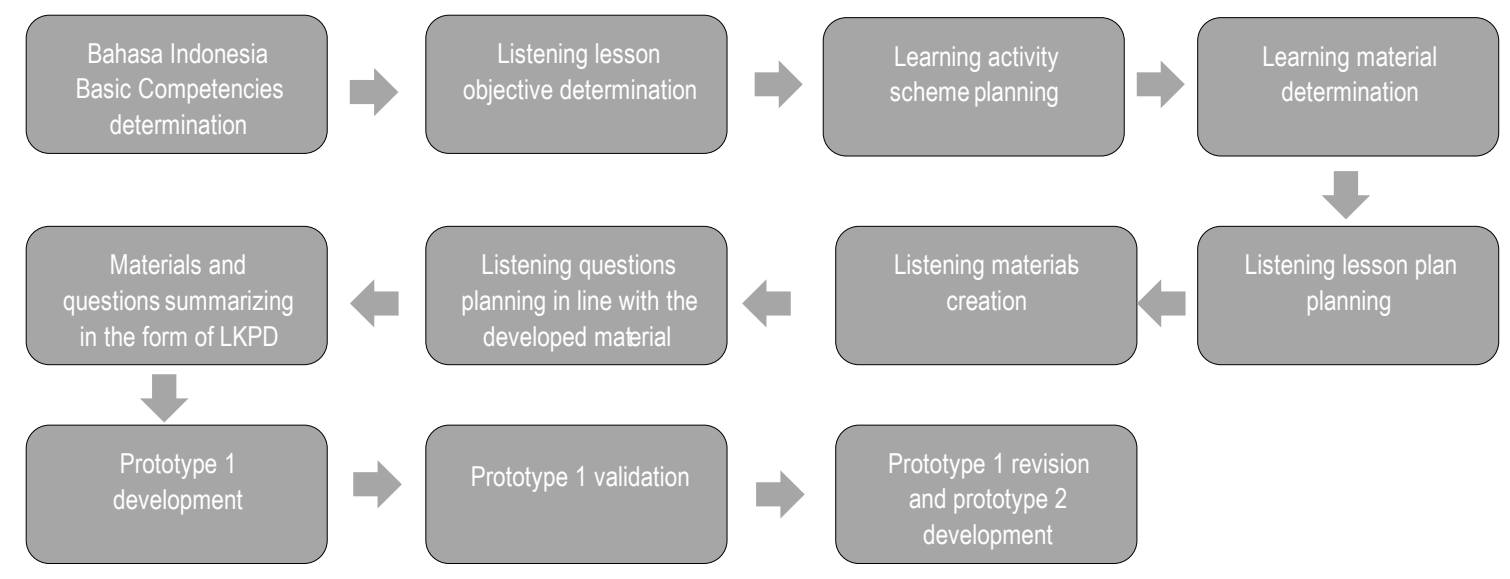

Figure 1. Prototype Development Process 
Katarina Retno Triwidayati \& Tresiana Sari Diah Utami, A Listening Lesson Prototype for the First-Grade...

The first step in conducting this research was analyzing Basic Competencies (KD, Kompetensi Dasar). The KD of the even semester was employed in this research as suggested by needs analysis results.

The teachers in the previous research also suggested developing materials for the even semester. This is because the odd semester of the first-grade is intended for introducing the school, adapting to primary school learning activities, and disciplining and growing positive habits for new students of primary school.

The even semester consists of two basic competencies. The basic competencies applied in this research can be seen in Table 2.

Table 2. Basic Competencies Employed in this Research

\begin{tabular}{|c|c|c|}
\hline No & Theme/ Sub Theme & Basic Competencies \\
\hline 1 & $\begin{array}{l}\text { My Experiences } \\
\begin{array}{l}\text { 1. Childhood experiences } \\
\text { 2. Experiences with friends } \\
\text { 3. Experiences at school } \\
\text { 4. Unforgettable } \\
\text { experiences }\end{array}\end{array}$ & $\begin{array}{l}\text { 3.8 Detailing expressions of thanking, apologizing, } \\
\text { helping, praising, inviting, giving information, giving } \\
\text { orders, and giving instructions to others using polite } \\
\text { spoken and written language with the possibility of } \\
\text { using local language vocabulary as an aid. }\end{array}$ \\
\hline 2 & $\begin{array}{l}\text { A clean, healthy, and beautiful } \\
\text { environment } \\
\text { 1. My home environment } \\
\text { 2. My neighborhood } \\
\text { environment } \\
\text { 3. My school environment } \\
\text { 4. Keeping the } \\
\text { environment clean and } \\
\text { healthy together }\end{array}$ & $\begin{array}{l}\text { 3.8 Detailing expressions of thanking, apologizing, } \\
\text { helping, praising, inviting, giving information, giving } \\
\text { orders, and giving instructions to others using polite } \\
\text { spoken and written language with the possibility of } \\
\text { using local language vocabulary as an aid. }\end{array}$ \\
\hline 3 & $\begin{array}{l}\text { Objects, animals, and plants } \\
\text { around us } \\
\text { 1. Living and non-living } \\
\text { objects around us } \\
\text { 2. Animals around me } \\
\text { 3. Plants around me } \\
\text { 4. The shape, color, size, } \\
\text { and surface of objects }\end{array}$ & $\begin{array}{l}\text { 3.6 Describing vocabularies on various types of } \\
\text { objects around through short texts (pictures, simple } \\
\text { slogans, texts, and/ or songs) and/ or exploring the } \\
\text { environment. } \\
\text { 3.8 Detailing expressions of thanking, apologizing, } \\
\text { helping, praising, inviting, giving information, giving } \\
\text { orders, and giving instructions to others using polite } \\
\text { spoken and written language with the possibility of } \\
\text { using local language vocabulary as an aid. }\end{array}$ \\
\hline 4 & Natural events & 3.6 Describing vocabularies on various types of \\
\hline
\end{tabular}


1. Afternoon and evening objects around through short texts (pictures, simple events

2. Dry season slogans, texts, and/ or songs) and/ or exploring the

3. Monsoon season environment.

4. Natural disasters 3.8 Detailing expressions of thanking, apologizing, helping, praising, inviting, giving information, giving orders, and giving instructions to others using polite spoken and written language with the possibility of using local language vocabulary as an aid.

Basic competencies in the Bahasa Indonesia subject were applied in this research, because Bahasa Indonesia is considered a bridge to science (Mahsun, 2014). In addition to affecting text-based learning, this idea also indicates two important points. Firstly, the affirmation that Bahasa Indonesia is the official language in Indonesia. Secondly, Bahasa Indonesia is used to transfer knowledge.

Moreover, the Basic Competencies of the Bahasa Indonesia subject were applied in this research was because the researcher wanted to harmonize the subject of Bahasa Indonesia with language skills. Thus, the learning activities must be in accordance with listening as the main activity.

Although this research employed Basic Competencies of the Bahasa Indonesia subject, Basic Competencies of other subjects may also be included in the learning activity. This is possible due to the fact that Kurikulum 2013 employs a thematic approach to teaching and learning. The notion is concretely realized by using basic competencies of the Bahasa Indonesia subject as the main listening material, and combining it with other subjects of the same theme.

Thematic learning, which combines more than one subject in one learning activity, aims at integrating the students' development and growth with their knowledge ability (Kadir \& Asrohah, 2014). This approach offered relevant and meaningful learning activities for the students, both in formal and informal activities, which are indicated through themes and sub-themes in the learning activity.

The Bahasa Indonesia subject materials were focused in the developed projects. However, there were several questions which were intended to discuss materials of other subjects. For example, in the Dry Season sub-theme, the researcher presented a listening material that discusses about the things that happen and what Palembang do in when the Dry Season approaches. One of the activities Palembang people do is burn fields and forests (Karhutla, Kebakaran Hutan dan Lahan) to open new fields. However, Karhutla has the potential to cause smog disaster. Evaluation questions can be 
Katarina Retno Triwidayati \& Tresiana Sari Diah Utami, A Listening Lesson Prototype for the First-Grade...

developed to discuss smog disaster and combine it with materials from other subjects (Triwidayati \& Utami, 2019). The discussion of the Karhutla case can be seen in Figure 2,

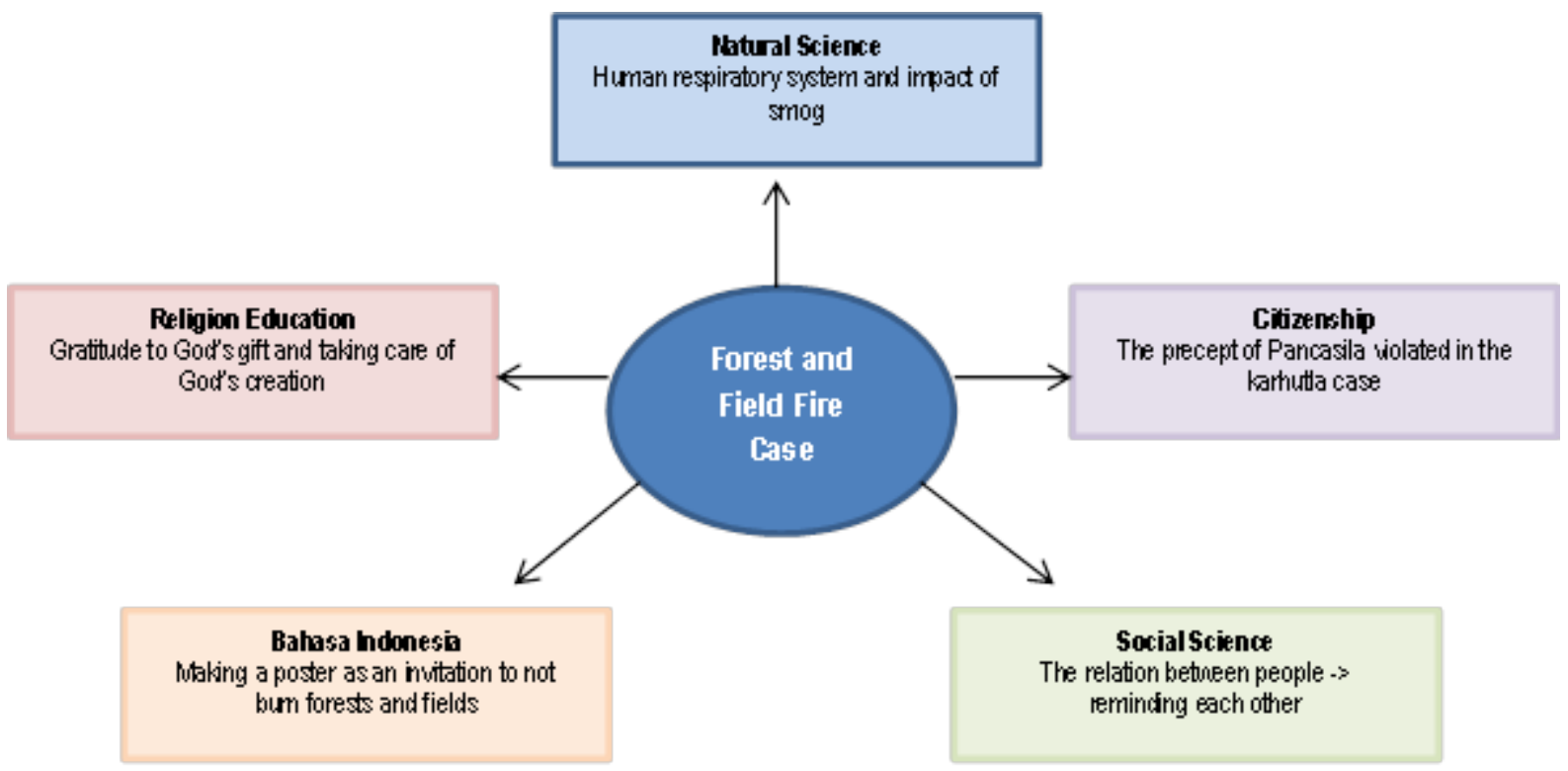

Figure 2. Example of Combining Materials Based on the Karhutla Case

After analyzing Basic Competencies, the researcher determined the learning objectives achievement indicators. The main target of this learning achievement is to understand the listening materials. Therefore, the objective of learning listening in the developed prototype is the students understand the listening materials of the intended Basic Competencies correctly. The determination of the learning indicators took into account audience, behavior, condition, and degree $(A B C D)$ factors. The intention was to ease the grading procedure.

Thus, a single learning scheme was used for all listening activities of the 16 sub- themes. The duration of one learning scheme is one credit hour or 35 minutes.

The developed learning scheme in this research is standard. Before the lesson begins, the teacher needs to prepare the students. After that, the students listen to the listening material using the listening media developed. Once the students have listened to the material, they are asked to fill in the worksheet, and discuss the results of their listening. To end the lesson, a reflection session is conducted to gain feedback for the listening activity.

The scheme of the learning activity is illustrated in the following diagram 


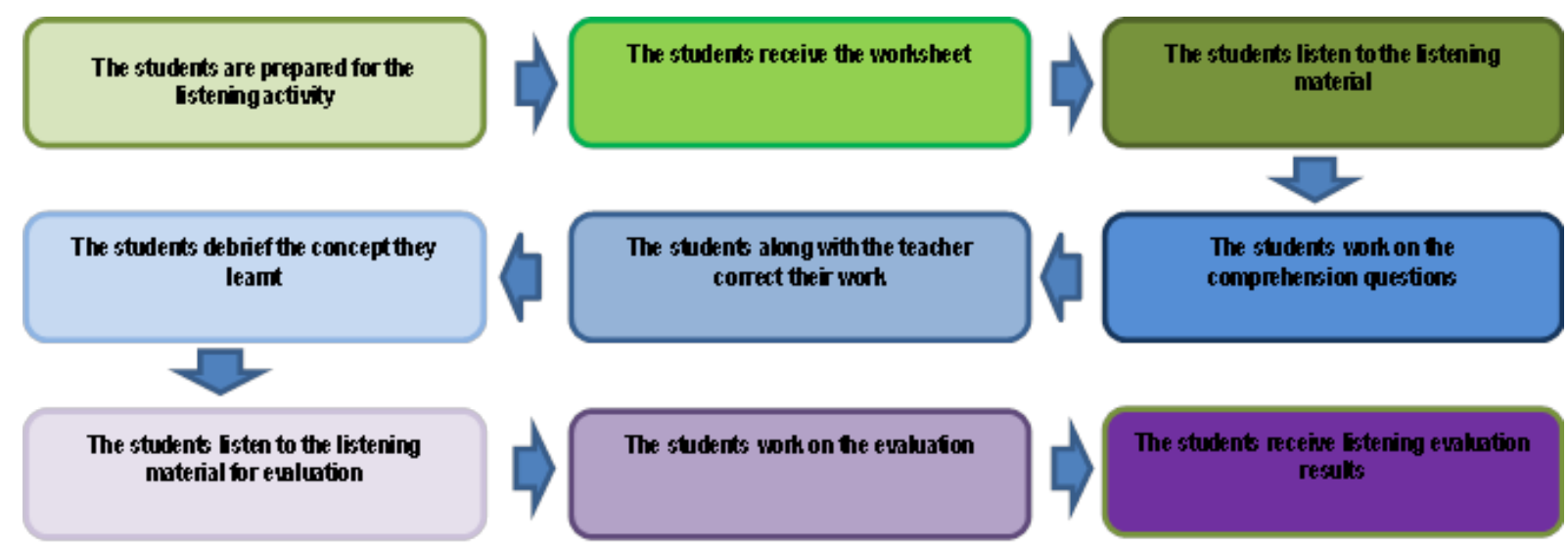

Figure 3. Scheme of the Learning Activity

In order to translate the learning scheme, the validators suggested developing a Lesson Plan (RPP, Rencana Pelaksanaan Pembelajaran). Hence, the researcher developed an RPP applicable for all materials in this research.

Besides that, the validators also stated that scientific learning needs to be included in the learning scheme. Therefore, the researcher included cases to each material enabling students to have group discussions.

The evaluation for the listening activity is based on each sub-theme. The test form and also number of items for each test is shown in the following table

Table 3. Test Form and Number of Items in each Theme

\begin{tabular}{|c|c|c|c|c|}
\hline No & Theme & Sub-theme & $\begin{array}{l}\text { Type of } \\
\text { Listening } \\
\text { Question }\end{array}$ & $\begin{array}{l}\text { Number of } \\
\text { Items }\end{array}$ \\
\hline 1 & \multirow{4}{*}{ My experiences } & Childhood experiences & Multiple choice & 5 \\
\hline 2 & & Experiences with friends & Multiple choice & 10 \\
\hline 3 & & Experiences at school & Closed test & 20 \\
\hline 4 & & Unforgettable experiences & Short answer & 5 \\
\hline 5 & \multirow{4}{*}{$\begin{array}{l}\text { Clean, healthy, and } \\
\text { beautiful environment }\end{array}$} & My house environment & Multiple choice & 5 \\
\hline 6 & & $\begin{array}{ll}\text { My } & \text { neighborhood } \\
\text { environment } & \end{array}$ & Multiple choice & 5 \\
\hline 7 & & My school environment & Short answers & 6 \\
\hline 8 & & $\begin{array}{l}\text { Keeping a clean and } \\
\text { healthy } \\
\text { together }\end{array}$ & Closed test & 15 \\
\hline 9 & \multirow{2}{*}{$\begin{array}{l}\text { Objects, animals, and } \\
\text { plants around me }\end{array}$} & $\begin{array}{l}\text { Living and non-living objects } \\
\text { around me }\end{array}$ & Closed test & 11 \\
\hline 10 & & Animals around me & Closed test and & 13 and 7 \\
\hline
\end{tabular}


Katarina Retno Triwidayati \& Tresiana Sari Diah Utami, A Listening Lesson Prototype for the First-Grade...

\begin{tabular}{|c|c|c|c|c|}
\hline & & \multicolumn{3}{|c|}{ matching } \\
\hline 11 & & Plants around me & Closed test & 19 \\
\hline 12 & & $\begin{array}{l}\text { The shape, color, size, and } \\
\text { surface of objects }\end{array}$ & Multiple choice & 10 \\
\hline 13 & & $\begin{array}{l}\text { Afternoon and evening } \\
\text { events }\end{array}$ & Closed test & 20 \\
\hline 14 & Natural events & Dry season & Closed test & 19 \\
\hline 15 & & Monsoon season & Closed test & 18 \\
\hline 16 & & Natural disasters & Closed test & 15 \\
\hline
\end{tabular}

Based on the table above, the number of items for each sub-theme differs. As a result, the validators suggested conducting validity and reliability tests to improve the validity of the test. Apart from that, the validators also suggested that each test type should have the same number of items. In other words, the test form, number of items, and duration for the test needs to be adjusted.

Nevertheless, the researcher did not revise the evaluation section since preliminary field test will be conducted in the next research. In the preliminary field test, the researcher identified the items considered acceptable, inacceptable, and needs revision. Therefore, having different number of items for each sub-theme is still possible.

The prototype also included Student's Worksheet (LKPD, Lembar Kerja Peserta Didik). The LKPD consists of two parts. The first part is for teachers, which includes listening lesson objectives, listening materials, comprehension questions, answer key, and grading guide.
Meanwhile, the second part of the LKPD is for students, which includes the learning objectives, comprehension tests, and feedback columns consisting of grade and reflections columns for students to write about their learning experience with the listening material.

The researcher prepared two forms of reflections for the students. The students can fill in the reflection column by writing about their experience in learning listening. However, the students may also fill in the column with emoticons to express how they feel about the listening lesson.

With the feedback column, teachers are expected to not only understand how the students think and feel, but also help develop the students' sense of empathy. In other words, apart from developing the students' listening skills, the purpose of learning listening is to facilitate the students' self-development through reflection.

The researcher's idea above is based on the thought that a good learning process can only be achieved if a two-way 
communication between the students and teacher is established. This is in line with Gilman who stated that a learning process based on listening to one other will make the learning activity more meaningful. This is because teachers and students will initiate a new and better understanding about each other (Gilman, 2018).

In the developed prototype, the purpose of the reflection column was to establish a two-way communication between the teacher and students. Moreover, parents also have access to the reflection page. So, parents are also expected to play a role in the development of their child's emotional quotient by discussing the results of reflection.

The other importance of the reflection column is that it allowed the researcher to provide cases for discussions. The discussions may either be between student and student, or student and teacher. Through discussions, students have the opportunity to develop their speaking skills apart from listening to ideas of other students or the teacher. In discussions, there is a possibility of having different opinions. Therefore, the students will be trained to tolerate others' opinions and can later be used to write reflections.

However, according to the validators, it was not clear on how to use the reflection column since the column is empty. Nevertheless, the validators approved the concept of combing the listening lesson with other skills and subjects.
Regarding the effectiveness of the feedback column, the validators stated that it cannot be implemented in this second phase, because the developed prototype was finalized in the odd semester. Meanwhile, the prototype is intended for the even semester. Therefore, further research is required to conduct the preliminary field test in order to test the listening materials, questions, and feedback form.

\section{CONCLUSION}

The results revealed that the listening lesson prototype was valid but needs to be revised. The revised section of the prototype was the listening activity scheme. Initially, the scheme was in the form of a diagram, which then improved by developing a lesson plan. The developed lesson plan is standard, so it can be used for all materials and basic competencies in this research. However, the comprehension questions were not revised because the preliminary field test will be conducted in the further research. In the preliminary field test, the researcher will calculate to identify the questions considered valid and reliable in order to determine the questions, which are acceptable, unacceptable, and needs to be revised. Moreover, the researcher was not able to test the effectiveness of the feedback column.

The researchers suggest other researchers to continue this research. The fact that listening lessons have not yet been 
Katarina Retno Triwidayati \& Tresiana Sari Diah Utami, A Listening Lesson Prototype for the First-Grade...

implemented effectively in primary school needs further attention. Therefore, the opportunity to develop a listening lesson design is still wide open.

\section{ACKNOWLEDGMENTS}

This research was funded by the Directorate for Research and Community Services and Directorate-General for Research Strengthening and Development in accordance with the Research Contract of the 2019 Budget, Number 830/SP2H/LT/MONO/L2/2019. The aforementioned research is entitled "A Prototype of Listening Learning for the FirstGrade in Primary School" conducted by Triwidayati and Utami.

This research was conducted to plan thanks to the support of all parties involved. For that reason, the research team would like to acknowledge the Directorate for Research and Community Services, the Institute for Research and Community Services (LPPM, Lembaga Penelitian dan Pengabdian pada Masyarakat) of Universitas Katolik Musi Charita, Palembang, Yayasan Xaverius Palembang, the participating schools in this research (SD Xaverius 3, SD Xaverius 4, SD Xaverius 5, SD Xaverius 6, SD Xaverius 8, dan SD Xaverius 9), the validators team, and the supporting team of this research of Laskar Literasi Iwak Tempalo (LITe).

\section{REFERENCES}

Bran, R. (2018). The Role of Active Listening in The Acquisition of Second Languages. Spring, 88-95. Retrieved from https://www.ceeol.com/search/arti cle-detail?id $=692707$

Gall, M. D., Gall, J. P., \& Borg, W. R. (2003). Educational Research: An Introduction. London: Logman Inc.

Gilman, S. S. (2018). Developing a Pedagogy of Listening: Experiences in an Indigenous Preschool. Studies In Social Justice, 12(2), 345-355. DOI: 10.26522/ssj.v12i2.1631

Kadir, A., \& Asrohah, H. (2014). Pembelajaran Tematik. Jakarta: Rajagrafindo Persada.

Mahsun. (2014). Teks dalam Pembelajaran Bahasa Indonesia: Kurikulum 2013. Jakarta: Rajawali Pers.

Supharatypthin, D. (2014). Developing Students' Ability in Listening and Speaking English Using The Communicative Approach of Teaching. International Journal of Arts \& Sciences, 12(1), 141-149. DOI: 10.9767/bcrec.12.1.621.89-95

Triwidayati, K. R. (2018). Pelaksanaan Pembelajaran Menyimak di SD Xaverius di Bawah Naungan Yayasan Xaverius Palembang. PGSD Musi, 1(1) 53-64. DOI: 10.32524/jpgsdm.v1i1.297

Triwidayati, K. R., \& Utami, T. S. D. (2019). Pengembangan Materi Simakan Berbasis Kearifan Lokal Untuk Kelas 1 Sekolah Dasar. Jurnal PGSD Musi, 2(1), 61-69. DOI: 10.32524/jpgsdm.v2i1.594

Utami, T. S. D., \& Triwidayati, K. R. (2016). Analisa Kebutuhan Media Pembelajaran Menyimak di Sekolah Dasar. Palembang: Universitas Katolik Musi Charitas.

Widyaningrum, H. K. (2015). Penggunaan Media Audio untuk Meningkatkan Kemampuan Menyimak Dongeng Anak pada Siswa Kelas IV Sekolah Dasar. Premiere Educandum, 5(2), 200-209. DOI: 10.25273/pe.v5i02.284 